Review of

ECONOMICS

and

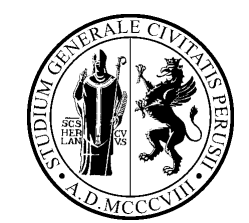

www.rei.unipg.it

\title{
Service Off-shoring and Productivity Growth in the European Economies
}

\author{
Cecilia Jona-Lasinio ${ }^{\bowtie}$ \\ LUISS Lab of European Economics \\ (LLEE) \\ and \\ Italian Institute of Statistics \\ (ISTAT)
}

\begin{abstract}
We study the relation between service off-shoring and productivity growth in the manufacturing sector of a set of European economies in 1995-2005. We document that those countries resorting more to service off-shoring in 1995 experienced faster productivity growth in ICT/R\&D intensive industries over the next decade. Our results show also that the productivity gap between more and less ICT/R\&D intensive industries was relatively higher in those countries experimenting higher increases in service offshoring intensity over the period. In both cases, ICT intensity is more relevant than R\&D to explain the mechanism through which service off-shoring affects productivity growth. These findings are consistent with the enhancing productivity effects of the complementary relation between service off-shoring and ICT.
\end{abstract}

JEL classification: O4, O3, F23

Keywords: Service off-shoring; Productivity growth; ICT

Address: LLEE Viale Romania 32, 00100 Rome, Italy (Phone: +3946736355 Email: cjonalasinio@luiss.it).

\section{Recommended Citation}

Jona-Lasinio, C. (2015). Service Off-shoring and Productivity Growth in the European Economies. Review of Economics and Institutions, 6(2), Article 4. doi: 10.5202/rei.v6i2.185.

Retrieved from http://www.rei.unipg.it/rei/article/view/185 


\section{Introduction}

In recent years, international outsourcing of production has expanded considerably in most of Western economies. The increasing role of offshoring has been favoured by the interplay between three factors: advances in technology, economic and competitive pressures to reduce costs and improve productivity, and institutional developments favouring trade liberalisation. In particular, the progress in Information and Communication Technologies (ICT) facilitated the tradability of services so that one of the most significant changes in economic activity over recent years has been the substantial growth of service off-shoring (Abramovsky and Griffith 2006; 2009). So far, most of existing empirical evidence on the economic impact of international outsourcing has been primarily focused on its potentially negative effects on domestic employment (Feenstra and Hanson 1996; Olsen 2006; Blinder 2007). Conversely, much less attention has been devoted to the impacts on productivity growth. The limited available evidence from OECD countries on the relation between off-shoring and productivity growth shows that in the US industries the off-shoring of services has been associated with productivity gains, while the evidence for intermediate offshoring is more mixed (Amiti and Wei 2009). As to European countries, the evidence of a positive correlation between service off-shoring and productivity is there for English-speaking countries, such as Ireland and the UK (Görg et al. 2007) but not for Italy (Daveri and Jona Lasinio 2008). Again, the evidence for intermediates is not unique; it is either insignificant or outright negative depending on industries and countries ${ }^{1}$ The aim of this paper is to provide empirical evidence on the relation between service off-shoring and productivity growth in a sample of European economies. We apply the approach proposed by Rajan and Zingales (1998) to investigate the mechanism through which service off-shoring affects economic growth. To this end, we look at the average effect of service off-shoring on productivity in the manufacturing industry across countries. Our main assumption is that service off-shoring is given for all manufacturing industries within a country but its impact could be different if industries differ as to the degree of technological development. The literature on trade and growth provides evidence of the productivity enhancing effect of trade specialization (Grossman and Helpman 1991) that is generally stronger in more technologically advanced sectors. If this is the case, it is reasonable to assume that the productivity benefits of service off-shoring are relatively higher in more innovative sectors. Then the relevance of off-shoring for productivity growth can be tested looking at whether more technological advanced industries perform relatively better in countries with higher service off-shoring intensity. ICT intensive industries are good candidates in this respect. As shown

1 See for example Görg and Hanley (2005) and Görg et al. (2008). 
in the empirical literature on ICT and growth, the firms that invest more in ICT and make complementary changes to their internal organization, as implied by the off-shoring of business activities previously performed in house, are more productive (Brynjolfsson and Hitt 2000; Bresnahan et al. 2002; Bloom et al. 2007). Moreover, Abramovsky and Griffith (2006) found that more ICT intensive firms purchased a greater amount of services in the market and they were more likely to purchase off-shore than less ICT intensive firms. Therefore ICT intensive firms should be better able to benefit from service off-shoring because of the way in which ICT eases business interactions (Brynjolfsson and Hitt 2000, 2003). The ICT adoption facilitates the off-shoring of firm's non-core business processes to specialized business providers allowing them to improve their performance by concentrating on their main production activities. Thus the complementarities between ICT and business service off-shoring generate productivity gains in ICT intensive industries (Abramovsky and Griffith 2009).

More generally, the main channels through which off-shoring may influence industry productivity involve compositional or structural effects. It may entail a static effect on efficiency due to specialization, for the offshoring firm, by its decision to outsource, can relocate fragments of production, less efficiently implemented in house, to a subsidiary located abroad. This process may involve positive or negative productivity effects for the plant located in the country of origin, depending on the type of activities being off-shored. This same process may also take place between rather than within firms. The off-shoring of activities would thus entail some resource reallocation with the related productivity effects for the industry rather than for the firm itself. Finally, and perhaps more conjecturally, off-shoring may also originate in dynamic efficiency effects. This may be due to "learningby-offshoring" effects if firms improve their methods of operation by importing back the services produced by the off-shored inputs, or thanks to the use of bigger or newer varieties of new materials or services (Amiti and Wei 2009). However, with our industry-country data we will not be able to single out which one of these channels is more relevant empirically. We will focus instead on country capacity to trade services and on its effect on productivity growth. To investigate this effect we use cross-country sector data for a set of EU economies in the period 1995-2005. Our results indicate that service off-shoring has a positive impact on productivity growth in more technological intensive industries. We find that relatively to the country and sector averages, the productivity growth differential between low and high ICT intensive industries is higher in more than in less service off-shoring oriented countries. The productivity growth differential can be 2.2 percent higher in those countries resorting relatively more to service offshoring over the period.

The paper is structured into five sections. The next section illustrates the data and measurement issues whilst section 3 provides a picture of produc- 
tivity performances and service off-shoring propensity across EU countries. Section 4 describes our empirical strategy and results. Section 5 concludes indicating the next steps in our research.

\section{Off-shoring measures and data}

In this section, we describe the measurement issues related to the offshoring indicators and our database.

\section{Measuring off-shoring intensity at the country/industry level}

Definition "Outsourcing" is the purchase of intermediates and services outside a manufacturing company which were previously performed by inhouse employees. In turn, outsourcing may take place in various guises, within or outside the country. If the outsourced inputs or services are produced outside the country, this is labeled "off-shoring" (or "off-shore outsourcing").

Measurement methods The measure of off-shoring intensity at the national level is generally obtained aggregating over sectoral measures. Depending on data availability one can compute direct and indirect off-shoring indexes..$^{2}$ When information on imported inputs is not available, the standard practice is to compute the Feenstra and Hanson (FH) indexes based on the import proportionality assumption (FH 1996). The FH broad index is the following:

$$
F H=\sum_{j} \frac{X_{j}^{i}}{Y_{i}} \times \frac{M_{j}}{C_{j}}
$$

where $X_{j}^{i}$ is input purchases of good $j$ by industry $i, Y_{i}$ is total non-energy input used by industry $i, M_{j}$ is import of good $j$, and $C_{j}$ is the domestic demand of good $j$. This is what Feenstra and Hanson (1996) call a broad measure of foreign outsourcing, i.e. the share of imported intermediate inputs over total intermediate costs. Based on this measure they also define a narrow measure of off-shoring by restricting the attention to those inputs that are purchased from the same industry as the one in which the good is being produced. The narrow index is obtained when $i=j$ in equation (1).$^{3}$ If instead Input-Output tables are available, direct measures of offshoring intensities can be calculated following the broad and narrow definitions described above but, at variance with Feenstra and Hanson, abandoning the so called "proportionality" assumption that any manufacturing industry would resort to intermediates or market services to the same extent. Instead, using the industry data on imported intermediates provided

2 As shown in Daveri and Jona Lasinio (2008), the choice of off-shoring measures (direct vs indirect) may significantly affect the result of the analysis.

3 They also calculate a differential measure of outsourcing as the difference between their broad and narrow off-shoring measures. 
by import matrices, it is possible to look directly at the value of imported intermediate inputs or services of each industry from and within each sector. The direct measure of broad off-shoring is thus:

$$
F H=\sum_{j} \frac{Z_{j}^{i}}{N_{i}}
$$

where $Z_{j}^{i}$ is the import of intermediate inputs of service (good) $j$ by industry $i, N_{i}$ is the amount of total non-energy intermediate inputs used by industry $i$. This index measures the broad off-shoring of services as the share of imported business and financial services over total non-energy intermediates. The same index can be used to measure the broad off-shoring of intermediates. Country service off-shoring measures are then obtained aggregating the above measures over the manufacturing industries. Thus our aggregate service off-shoring index is referred to the manufacturing sector as a whole in each country.

Data Our basic data source consists of EUROSTAT input-output tables available for the following countries and time periods: Belgium (1995-2000), Denmark (1995-2004), Germany (1995-2005), France (1995-2005), Italy (19952005), Netherlands (1995-2004), Austria (1995-2000), Finland (1995-2005), Sweden(1995-2000) and UK (1995-2000). Data on output and factor inputs are taken from the EUKLEMS and OECD data sets providing very detailed industry information for European countries and the US for the period 19952005.

\section{Service Off-shoring and Productivity Growth}

\subsection{The Cross-Country Cross-Industry Dimension of Interme- diate Trade}

The empirical literature has not provided, until now, a clear evidence of a positive impact of off-shoring on productivity growth. A possible reason is that the productivity enhancing effects of off-shoring depend on some country and firm characteristics as well as market or institutional factors (Liu et al. 2011). Further, most of the literature on intermediate trade focused on the determinants of off-shoring and on those factors influencing the choice of the off-shoring location (Antràs and Helpman 2004); Grossman and Helpman 2005). These studies model off-shoring as a contractual relationship between domestic outsourcing firms and foreign input providers. Liu et al. (2011), for example, investigate the relevance of transaction costs (Williamson 1979) in understanding the determinants of service off-shoring, since factors that lower transaction costs are supposed to increase the amount of off-shoring. They show that there are various country characteristics 
that can influence the off-shoring outsourcing relationship (Anderson and Gatignon 1986) such as the quality of institution in the foreign country and the cultural proximity. Better legal institutions are inclined to ensure the enforcement of contracts and encourage greater transparency in the business environment (Nunn 2007). Then the better the quality of the institutional environment, the lower the transaction costs involved in an off-shoring relationship, the higher the off-shoring intensity in the country. Cultural proximity, on the other hand, is expected to reduce asymmetric information and luck of trust between the outsourcing company and the foreign service provider (Leamer and Storper 2001). As a consequence, transaction costs should be lower for off-shoring to countries with greater cultural proximity. Liu et al. (2011) show that the propensity of service off-shoring is positively correlated with both institutional quality and cultural proximity as well as with other country characteristics such as education level, ICT infrastructure and the size of GDP.

In this paper, we document the existence of some differences of service off-shoring intensities among EU countries and we do not focus on the determinants of service off-shoring at the national level but we take it as given. Instead, we analyse the impact of this predetermined service off-shoring propensity on productivity growth.

\section{Table 1 - Service Off-shoring as a Percentage of EU average}

\begin{tabular}{|c|c|c|c|c|c|c|c|c|c|c|c|c|c|}
\hline & EU & $\mathbf{A U}$ & $\mathrm{BE}$ & $\mathrm{DE}$ & DK & FI & FR & IT & NL & SWE & IR & PT & SP \\
\hline Construction & 1.8 & 0.6 & 1.3 & 0.3 & 1.0 & 0.6 & 1.1 & 0.7 & 1.4 & 3.5 & 0.1 & 0.3 & 1.2 \\
\hline Wood and Products Of Wood and Cork & 1.9 & 0.7 & 2.0 & 0.5 & 1.1 & 1.1 & 0.7 & 1.7 & 0.6 & 1.7 & 1.3 & 0.3 & 0.2 \\
\hline Basic Metals and Fabricated Metal Products & 2.0 & 0.9 & 1.9 & 0.8 & 0.9 & 0.9 & 0.6 & 0.7 & 1.5 & 1.5 & 1.2 & 0.4 & 0.5 \\
\hline Food Products, Beverages and Tobacco & 2.0 & 0.5 & 1.5 & 0.4 & 0.9 & 0.9 & 0.6 & 0.5 & 0.6 & 1.3 & 2.8 & 0.3 & 1.6 \\
\hline Transport Equipment & 2.1 & 0.3 & 0.8 & 0.6 & 0.9 & 0.8 & 0.5 & 0.9 & 0.5 & 2.9 & 1.7 & 0.1 & 1.9 \\
\hline Other Non-Metallic Mineral Products & 2.6 & 0.8 & 1.9 & 1.3 & 1.0 & 1.3 & 0.8 & 0.7 & 0.7 & 2.5 & 0.3 & 0.4 & 0.4 \\
\hline Textiles, Textile Products, Leather and Footwear & 2.7 & 0.8 & 1.1 & 0.2 & 1.3 & 1.1 & 0.5 & 0.9 & 0.7 & 1.6 & 2.8 & 0.2 & 0.8 \\
\hline N.E.C. & 2.9 & 0.8 & 1.4 & 0.5 & 1.0 & 1.5 & 0.5 & 1.0 & 0.8 & 1.6 & 1.4 & 0.3 & 1.2 \\
\hline Manufacturing Nec; Recycling & 3.0 & 0.6 & 0.7 & 0.3 & 1.4 & 0.9 & 0.4 & 1.0 & 1.3 & 1.3 & 3.1 & 0.3 & 0.8 \\
\hline Electricity Gas and Water Supply & 4.5 & 0.7 & 1.8 & 0.5 & 0.9 & 1.6 & 0.8 & 1.7 & 0.7 & 0.8 & 1.2 & 1.0 & 0.3 \\
\hline Electrical and Optical Equipment & 5.6 & 0.2 & 1.0 & 0.3 & 0.3 & 1.0 & 0.2 & 1.0 & 2.3 & 1.6 & 3.5 & 0.1 & 0.5 \\
\hline Pulp, Paper, Printing and Publishing & 8.8 & 0.1 & 0.6 & 0.2 & 0.3 & 0.4 & 0.2 & 0.2 & 0.4 & 0.5 & 8.7 & 0.1 & 0.2 \\
\hline Chemical, Rubber, Plastics and Fuel Products & 9.1 & 0.2 & 0.5 & 0.5 & 0.5 & 0.4 & 0.2 & 0.3 & 0.3 & 1.1 & 7.2 & 0.1 & 0.7 \\
\hline Total & 48.9 & 0.4 & 1.1 & 0.4 & 0.7 & 0.8 & 0.4 & 0.8 & 0.8 & 1.4 & 4.1 & 0.3 & 0.7 \\
\hline
\end{tabular}

Table 1 compares the service off-shoring intensity distribution at the industry level for the twelve European countries selected. Our benchmark is shown in the first column displaying the average service off-shoring intensities for the EU aggregate. Industries are ranked in increasing order of off-shoring intensity. The remaining columns report our index of service off-shoring for each country as a ratio to the EU average. The data indicate that, in 2000, the average manufacturing industry in Europe bought imported business services for some 48.9 percent of its total non-energy inputs. The more service off-shoring oriented sectors are chemicals, pulp and paper and electrical and optical equipment that are also the most technologically intensive industries in the manufacturing sector. The difference 
between the more (chemical) and the less (construction) off-shoring intensive sectors accounts for a factor of almost 7 . Also, the dissimilarities among countries are not small. Ireland has the largest mean size, four times higher than the EU average, followed by Sweden about 40 per cent higher and Belgium 10 percent higher. At the lower end, well below the EU average, there is Portugal and at the same level, Germany and France, with an average service off-shoring intensity equal respectively to 28 and 43 percent below the benchmark. Differences in off-shoring propensity across countries could be due to some national characteristics inducing such differences within a sector. The row variation is quite high in Table 1 , indicating that the same industry can be characterized by very different service off-shoring intensities in different countries. The sectors characterized by the most dispersed service off-shoring intensities are pulp and printing, chemical rubber and plastic, and electrical and optical equipment. As stressed above, these industries are also among the most technologically intensive sectors. The differences are significant also at the country level. In Austria and Portugal all sectors are below the EU average, in Germany and France all industries but one are below the average, while the opposite is true for Sweden and Ireland. Thus national characteristics, such as regulation in the factor markets, the quality of institutions, technological infrastructure or the level of education may be important determinants of service off-shoring propensity independently of sectoral specialization (Liu et al. 2011). This evidence provides us a motivation for looking at the country-industry dimension of the relation between service off-shoring and productivity growth.

\subsection{Service Off-shoring and Productivity Growth in the Eu- ropean Economies}

Before going into the details of the empirical analysis we look at the patterns of productivity and service off-shoring across the EU economies. In the second half of the 1990s, labour productivity growth in the EU economies (EU-15) slowed significantly from $2.7 \%$ in $1980-1995$ to $1.4 \%$ in $1995-2005$ (1.7 percent if measured for EU-25). But the data document a high degree of heterogeneity of productivity performances across EU countries. During the same period, most economies in the EU have been increasingly involved in the process of globalization that lead to delocalize abroad many manufacturing and service activities previously carried out within the domestic borders. Figure 1 shows the yearly average rates of growth of productivity and service off-shoring intensities in the manufacturing sectors across the EU economies ranked according to service off-shoring increases. In 1995-2005, the highest productivity growth rates were recorded in Ireland increasing at an average rate of $4.4 \%$ per year, followed by Finland and Sweden increasing on average $2.5 \%$ per year. Among the large EU economies, France and Germany increased at $1.8 \%$ and $1.6 \%$ per year respectively (from 3.2\% and 
Figure 1: Labor Productivity and Service Off-shoring Intensities 1995-2005 (compounded average rates of growth)

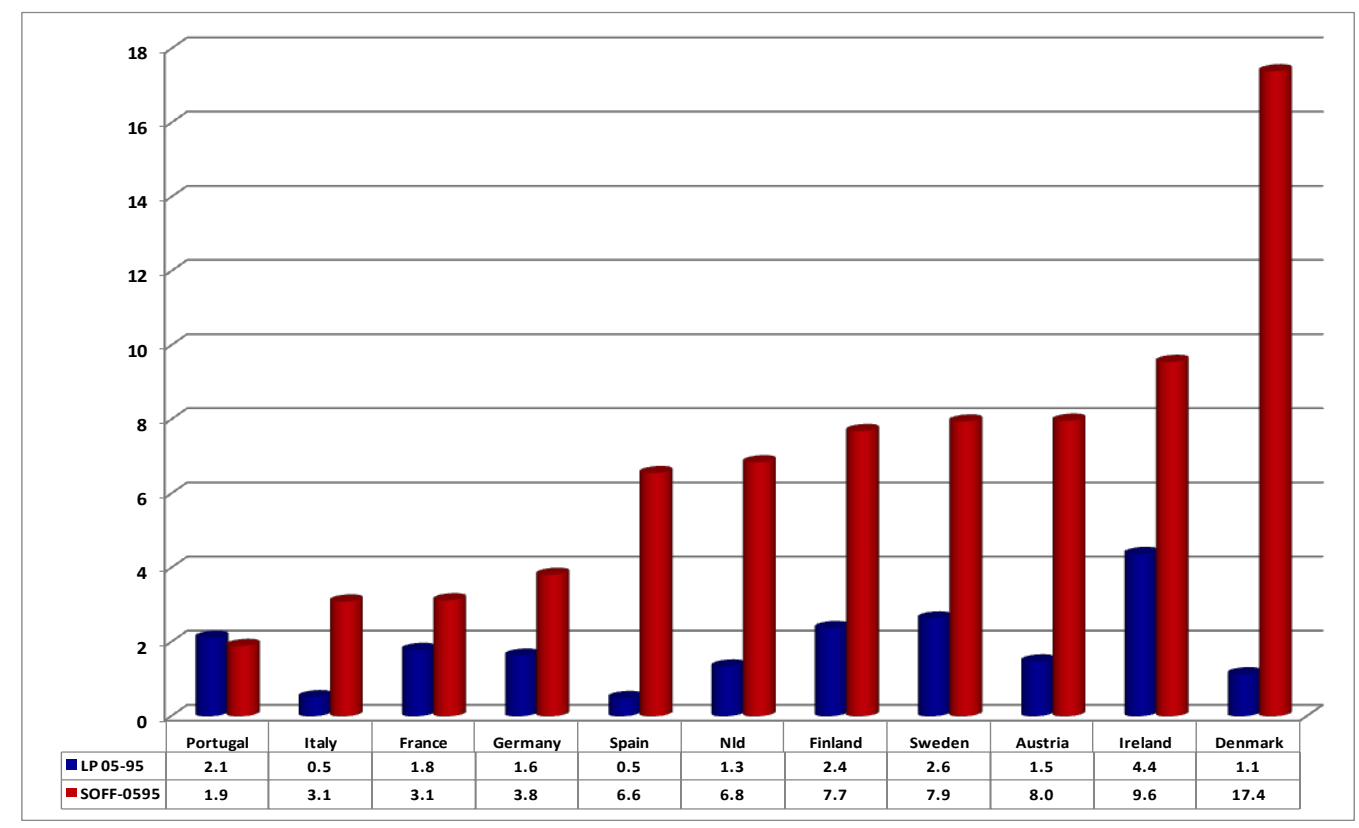

$2.8 \%$ in 1970-1995). At the lower end of productivity ranks are Italy (0.5\% vs $2.4 \%$ in $1970-1995)$ and Spain $(0.5 \%$ vs $2.9 \%$ in $1970-1995)$ whose dismal productivity performance impacts significantly on the average growth rate of the Union (OECD 2007). The data in Figure 1 show also that the share of imported intermediate services increased in all countries over the decade even if at different pace across Europe. Service off-shoring increased at a faster rate in Denmark (17.4\% per year), Ireland (9.6\% per year), Austria ( $8 \%$ per year), Sweden and Finland (7.9\% and $7.7 \%$ respectively); while it increased at a slower pace in some of the Continental European economies such as Germany (3.8\% per year), France and Italy (3.1\% per year) and Portugal $(1.9 \%$ per year $)$.

Figure 2 shows service off-shoring intensities for the manufacturing sectors in the selected EU economies in 1995 and in 2005. At the beginning of the period, service off-shoring intensities varied from 0.7-0.9 per percent of Portugal, Denmark and Germany, to 3.9 percent of Finland and 3.0 percent of Sweden. Whilst in 1995 service off-shoring by manufacturing industries in the EU was a rather small phenomenon, it increased at a fast pace during the decade, even if in a differentiate manner across countries. In 2005, the share of imported services accounted for 6.4 percent of non-energy intermediate inputs in Sweden, 5.7 percent in Finland, 5.3 percent in Netherlands, 1.8 percent in Germany and 1.7 percent in France. To sum up, all together these data indicate that over 1995-2005, in most countries in the EU the slowdown of labour productivity growth was paralleled by a rising tendency to off-shore service activities. But the degree of the productivity slowdown 
Figure 2: Service Off-shoring intensities: 1995-2005 (percentage values)

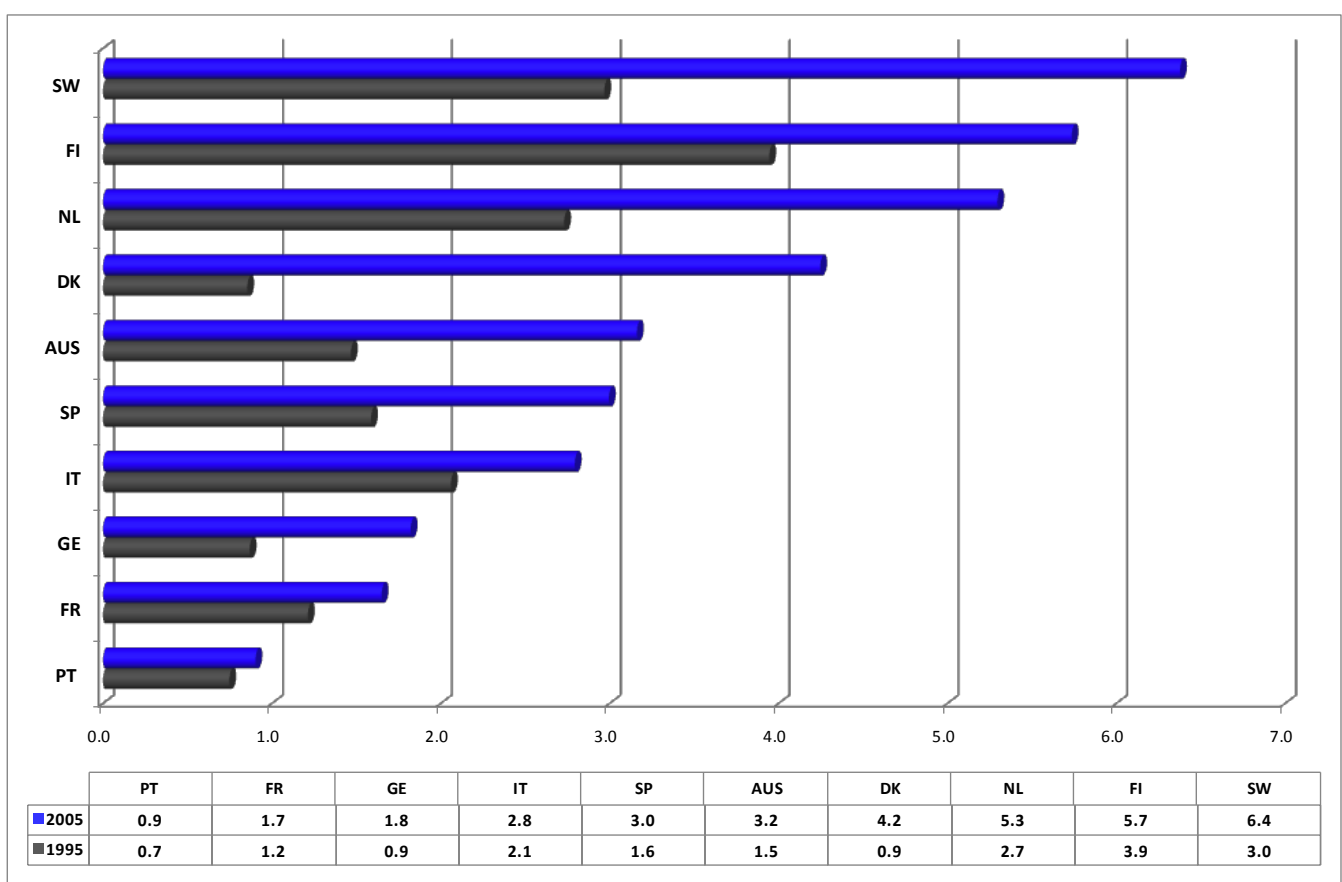

and the intensity of off-shoring varied considerably across them. More recent evidence, however, shows that off-shoring increased considerably up to 2009 when the financial crisis affected the strategies of internationalization of the firms. Since then, there has been an increasing tendency of bringing back home off-shored productive activities (re-shoring or back-shoring) ${ }^{4}$ with a consequent decline of offshoring propensity (Frattocchi et al. 2014).

\section{Service Off-shoring and Productivity Growth: Statistical Evidence}

In this section we first describe our empirical strategy and then present the main findings on the relation between service off-shoring and productivity growth in the EU manufacturing industries.

\subsection{Empirical strategy}

To analyze the relation between service off-shoring and productivity growth we adopt the cross-industry cross-country approach of Rajan and Zingales (1998) that has been widely implemented in growth empirics. It has been applied mostly in finance (Braun and Larrain 2005; Cetorelli and Stra-

\footnotetext{
${ }^{4}$ See Liu and Trefler (2008) for the analysis of the consequences of inshoring activities on employment.
} 
han 2006; Aghion et al. 2007; Fisman and Love 2007; Beck et al. 2008; Manova 2008); to analyze the effects of labor market institutions on comparative advantage and productivity (e.g. Cingano et al. 2010; Cuñat and Melitz 2012), to investigate the relation between human capital and comparative advantage (e.g. Romalis 2004; Ciccone and Papaioannou 2009); and to examine the economic consequences of firm size, entry regulation, transaction costs, fiscal policy, risk sharing, and foreign aid (e.g. Pagano and Schivardi 2003; Klapper et al. 2006; Acemoglu et al. 2009; Aghion et al. 2014; Michelacci and Schivardi 2010; Rajan and Subramanian 2011). The main advantage of this approach is that it allows addressing directly the problem of reverse causality and to reduce the omitted variable bias frequently affecting cross country growth regressions 5 (Ciccone and Papaioannu 2010). To tackle the problem of reverse causality and omitted variables Rajan and Zingales (1998) suggest to define some industry characteristics that allow to rank sectors according to the relative importance of the variable of interest (financial development, firm size, human capital, etc.) for growth. In our analysis, this amount to identify those industries that should be affected most/less by service off-shoring activity. A good candidate in this respect is the ICT expenditure that displays a high degree of industry variability and, it should potentially be a channel through which service off-shoring affects productivity growth. The relationship between technology and off-shoring has been extensively investigated by Grossman and Helpman (2002) and (2005) and Antràs and Helpman (2004) in a model for off-shoring decisions where technology affects the cost of international outsourcing. In this framework, Abramovsky and Griffith (2009) found that more ICT intensive firms are more likely to off-shore services than less ICT intensive firms. The demand for off-shored services depends on the relative cost of producing services in-house compared to outsourcing. Since information technologies substantially reduce transaction and search costs of importing services, more ICT intensive firms will face lower relative cost of outsourced services and a greater demand for them. Abramovsky and Griffith (2009), show that investing in ICT increases the probability of off-shoring by $6 \%$.

\subsubsection{Empirical specification}

Our empirical specification follows closely Rajan and Zingales (2008) and subsequent literature (Ciccone and Papaioannou 2009). A common characteristic is that because of limitations to available international industrylevel data we also resort to U.S. data to get a proxy of global industry characteristic. But our aim is to exploit both cross-country and cross-industry variability to evaluate the effects of service off-shoring on productivity growth.

5 The main problem with growth regression is the difficulty to establish the direction of causality. This can be due to the explanantory variable being simply a leading indicator and not a causal factor of economic growth. Reverse causality and omitted variable problems can originate from that producing biased OLS estimates. 
To this end, we run a regression of sectoral growth on an interaction of the degree of country level service off-shoring and industry level technological development, after controlling for a set of country and industry dummies. Our growth regression is the following:

$$
g Y_{i j}=\beta_{0}+\beta_{1} X_{i j}+\beta_{2} \ln \left(O f f_{j} \times I C T_{i}\right)+\beta_{3} \ln \left(\Delta O f f_{j} \times I C T_{i}\right)+\delta_{i}+\mu_{j}+\epsilon_{i j}
$$

where $g Y_{i j}$ is the average rate of growth of value added per worker in country $j$ in sector $i ; X_{i j}$ are control variables; $O f f_{j}$ is the off-shoring intensity of services in country $j$ in a reference year; $I C T_{i}$ captures the differential industry effect of service off-shoring on growth, that is the intensity, $\delta_{i}$ and $\mu_{j}$ are a set of industry and country dummies, and $\epsilon_{i j}$ is an error term. We insert country dummies to ensure that our results are not driven by specific country characteristics that might potentially be correlated with our service off-shoring measure. Industry dummies should instead catch the possible correlation between specific industry characteristics and our measure of technological intensity. Therefore, to identify our parameters of interest we use within-country differences in industry growth rates. If our proxy is correct, we should find that the coefficients $\beta_{2}$ and $\beta_{3}$ in equation (3) are positive and significant indicating respectively that within each country industries that are more ICT intensive grow faster when the off-shoring intensity is higher in the beginning of the period and when service off-shoring increases over time. We first focus on the initial level effect of service offshoring so that the first set of our estimates refer to equation (3) without the $\beta_{3} \ln \left(\Delta O f f_{j} * I C T_{i}\right)$ term. Then we check the initial level effect taking into account also the improving effect of service off-shoring estimating equation (3) with both interaction terms.

\subsection{Industry Characteristics}

As mentioned before, to implement this model we need a measure of ICT intensity at the industry level external to our data set that should be a good proxy of ICT intensity for a "global industry". The relevant sectoral characteristic should be referred to an undistorted economy, where the ICT intensity of sectors is determined in an unconstrained environment. Most of the literature following the approach of Rajan and Zingales used US data to proxy global industry characteristics since they are less distorted compared to other developed economies (Ciccone and Papaioannou 2010). ${ }^{6}$ In our analysis, we use an indicator of ICT intensity at the industry level for the US economy. The US is a natural benchmark to determine ICT intensity in an unrestricted setting, given the low level of regulation in the American economy. We rank industries according to the US measure of ICT intensity

6 Ciccone and Papaioannou (2010) show that the use of industry characteristics in a benchmark country as a proxy for the relevant industry characteristics may introduce measurement error which can result in an attenuation bias and an amplification bias. 
and we consider whether the impact of service off-shoring varies systematically with it. The ICT intensity is measured as (ICT expenditure/Total employment $)_{i} i=1, . ., 14$ industries; we also test for R\&D intensity using the R\&D expenditure over total employment as an alternative technological intensity indicator (Table 2).

Table 2 - Technological intensities in the US: ICT vs R\&D

\begin{tabular}{lcc}
\hline & ICT-FTE & R\&D-FTE \\
Food Products, Beverages and Tobacco & 1.47 & 0.78 \\
Textiles, Textile Products, Leather and Footwear & 0.54 & 0.21 \\
Wood and Products of Wood and Cork & 0.51 & 4.80 \\
Pulp, Paper, Paper Products, Printing and Publishing & 2.44 & 1.26 \\
Chemical, Rubber, Plastics and Fuel Products & 4.00 & 10.61 \\
Other Non-Metallic Mineral Products & 1.67 & 1.42 \\
Basic Metals and Fabricated Metal Products & 1.31 & 0.25 \\
Machinery and Equipment, N.E.C. & 4.80 & 4.11 \\
Electrical and Optical Equipment & 5.72 & 25.62 \\
Transport Equipment & 3.30 & 13.76 \\
Manufacturing Nec; Recycling & 1.24 & 0.37 \\
Electricity Gas and Water Supply & 11.80 & 0.26 \\
Construction & 0.85 & 0.03 \\
Wholesale and Retail Trade; Repairs & 1.24 & 1.16 \\
Hotels and Restaurants & 0.18 & 0.00 \\
Transport and Storage & 6.71 & 0.37 \\
Post and Telecommunications & 30.67 & 1.39 \\
Financial Intermediation & 7.12 & 5.61 \\
Real Estate Activities & 1.69 & 9.88 \\
Renting of M\&Eq and Other Business Activities & 4.44 & 0.68 \\
\hline
\end{tabular}

\subsection{Results}

\subsubsection{Service Off-shoring and Productivity Growth: The Initial Effect}

Table 3 columns 1-3 report the estimates of the effect of initial service offshoring intensity on annual growth in more compared to less ICT intensive industries. The coefficient on initial service off-shoring intensity interaction is 0.0141 (col. 3) and statistically significant at the 1 percent level. It implies an annual growth differential of 0.15 percent (Table 5) between an industry at the 75th percentile (Electrical and Optical equipment) and an industry at the 25th percentile (Textile) of the ICT intensity distribution in a country with an initial service off-shoring intensity at the 75th percentile (Finland) compared to a country at the 25 th percentile (Germany). In columns 1 and 2 we test the robustness of our results to alternative determinants of sectoral productivity growth traditionally considered in the growth literature: physical and human capital intensities. Both variables are statistically significant and positive as expected. Colums 4-6 report the same estimates as of columns 1-3 but using R\&D instead of ICT intensity as an alternative 
measure of technological development in the interaction term.7 The growth differential between an industry at the 75th percentile (Chemical) and an industry at the 25th percentile (Textile) of the R\&D intensity distribution in a more (Finland) compared to a less (Germany) service off-shoring oriented country at the beginning of the period is 0.05 percent (Table 5 ). This finding confirms a positive initial effect of service off-shoring also in more as compared to less R\&D intensive industries. However, the differential effect of R\&D is lower than that of ICT.

Table 3 - Benchmark estimates - Level effects: Service Off-Shoring and Industry Productivity Growth

\begin{tabular}{|c|c|c|c|c|c|c|}
\hline \multirow[b]{3}{*}{ VARIABLES } & \multicolumn{6}{|c|}{ Manufacturing sectors 1995-2005 } \\
\hline & \multirow{4}{*}{$\begin{array}{c}\mathbf{1} \\
0.0134^{* * *} \\
(0.00167)\end{array}$} & \multicolumn{3}{|c|}{ OLS } & \multirow[b]{2}{*}{5} & \multirow[b]{2}{*}{6} \\
\hline & & 2 & 3 & 4 & & \\
\hline \multirow[t]{2}{*}{$\mathrm{OFF} \times \mathrm{ICT}$} & & $0.0129^{* * *}$ & $0.0141^{* * *}$ & & & \\
\hline & & $(0.00168)$ & $(0.00203)$ & & & \\
\hline \multirow[t]{2}{*}{$\mathrm{OFF} \times \mathrm{R} \& \mathrm{D}$} & & & & $0.00407^{* * *}$ & $0.00338^{* * *}$ & $0.00642^{* * *}$ \\
\hline & & & & $(0.000947)$ & $(0.000963)$ & $(0.00117)$ \\
\hline \multirow[t]{2}{*}{$\mathrm{K} / \mathrm{L}$} & $0.0657^{* * *}$ & $0.0654^{* * *}$ & & $0.0638^{* * *}$ & $0.0640^{* * *}$ & \\
\hline & $(0.00520)$ & $(0.00537)$ & & $(0.00528)$ & $(0.00546)$ & \\
\hline \multirow[t]{2}{*}{ HK } & $0.00632^{* * *}$ & & & $0.00664^{* * *}$ & & \\
\hline & $(0.00196)$ & & & $(0.00201)$ & & \\
\hline \multirow{2}{*}{$\begin{array}{l}\text { Initial conditions } \\
(\mathrm{VA} / \mathrm{L})\end{array}$} & $-0.128^{* * *}$ & $-0.127^{* * *}$ & $-0.0741^{* * *}$ & $-0.125^{* * *}$ & $-0.124^{* * *}$ & $-0.0710^{* * *}$ \\
\hline & $(0.00968)$ & $(0.00997)$ & $(0.00956)$ & $(0.0101)$ & $(0.0105)$ & $(0.00964)$ \\
\hline Observations & 781 & 781 & 781 & 781 & 781 & 781 \\
\hline R-squared & 0.751 & 0.747 & 0.645 & 0.737 & 0.733 & 0.638 \\
\hline Country fixed effects & yes & yes & yes & yes & yes & yes \\
\hline Industry fixed effects & yes & yes & yes & yes & yes & yes \\
\hline \multicolumn{7}{|c|}{$\begin{array}{l}\text { Note: OLS estimates, the dependent variable is the annual growth rate of value added per full time equivalent a } \\
\text { the country industry level for the period } 1995-2005 ; \text { OFF is service off-shoring intensity in } 1995 ; \text { ICT is the ratio o } \\
\text { ICT capital to full time equivalent employees in the US; R\&D is the ratio of R\&D expenditure to full time equivalen } \\
\text { employees in the US; K/L is the average capital per worker over the period; HK is an index of human capital; VA/L } \\
\text { is the real value added per worker at the beginning of the period. All the variables are in log. } \\
\text { Robust standard errors in parentheses. }{ }^{* \star *} p<0.01,{ }^{* *} p<0.05,{ }^{*} p<0.1 \text {. }\end{array}$} \\
\hline
\end{tabular}

\subsubsection{Service Off-shoring and Productivity Growth: The Improving Ef- fect}

The second set of our estimates accounts for the possibility that faster growth in ICT intensive industries might be driven also by increases in service off-shoring activity. Table (4) shows the results of the estimates of equation (3) including both interaction terms. Colum 3 reveals that there is a positive and statistically significant coefficient of $\beta_{3}$ indicating that labor productivity growth in ICT intensive industries was faster in countries experimenting higher increases in service off-shoring intensity over the period. To quantify this effect compare a country with an improvement of

\footnotetext{
7 Here we use the R\&D intensity as an alternative measure of technological innovation. At this stage, the aim is purely explorative simply to check for alternative channels through which service off-shoring may affect industry productivity growth. In future research work we will explore more deeply the role of a wider set of intangible assets.
} 
service off-shoring intensity at the 75th percentile (Denmark with an improvement of 75 percent) and a country at the 25 th percentile (Finland with an increase of 30 percent). Then the estimated coefficient on annual productivity growth gap between more (Electrical and optical equipment) and less (Textile) ICT intensive sectors is 2.2 percent higher in Denmark than in Finland. The interaction between initial service off-shoring and ICT intensity remains positive and statistically significant at the 1 percent level in all specifications. Further, point estimates are bigger than in the previous specification. The initial service off-shoring coefficient is now 0.0182 that is about 30 percent higher than the corresponding estimated coefficient in Table 3. As a result higher initial service off-shoring was coupled with faster productivity growth in ICT intensive sectors, even when increases in service off-shoring are accounted for.

Table 4 - Level and Growth Effects: Service Off-Shoring and Industry Productivity Growth

\begin{tabular}{|c|c|c|c|c|c|c|}
\hline \multirow[b]{3}{*}{ VARIABLES } & \multicolumn{6}{|c|}{ Manufacturing sectors 1995-2005 } \\
\hline & \multicolumn{6}{|c|}{ OLS } \\
\hline & 1 & 2 & 3 & 4 & 5 & 6 \\
\hline \multirow[t]{2}{*}{ OFF $x$ ICT } & $0.0157^{* * *}$ & $0.0150^{* * *}$ & $0.0182^{* * *}$ & & & \\
\hline & $(0.00195)$ & $(0.00200)$ & $(0.00240)$ & & & \\
\hline \multirow[t]{2}{*}{ DOFF $x$ ICT } & $0.00863^{* * *}$ & $0.00796^{* * *}$ & $0.0159^{* * *}$ & & & \\
\hline & $(0.00287)$ & $(0.00277)$ & $(0.00374)$ & & & \\
\hline \multirow[t]{2}{*}{ OFF $x$ R\&D } & & & & $0.00532^{* * *}$ & $0.00478^{* * *}$ & $0.00954^{* * *}$ \\
\hline & & & & $(0.00109)$ & $(0.00113)$ & $(0.00140)$ \\
\hline \multirow[t]{2}{*}{ DOFF $\times$ R\&D } & & & & $0.00478^{* *}$ & $0.00524^{* * *}$ & $0.0124^{* * *}$ \\
\hline & & & & $(0.00199)$ & $(0.00186)$ & $(0.00253)$ \\
\hline \multirow{2}{*}{$\mathrm{K} / \mathrm{L}$} & $0.0647^{* * *}$ & $0.0646^{* * *}$ & & $0.0622^{* * *}$ & $0.0622^{* * *}$ & \\
\hline & $(0.00506)$ & $(0.00524)$ & & $(0.00500)$ & $(0.00517)$ & \\
\hline \multirow[t]{2}{*}{ HK } & $0.00651^{* * *}$ & & & $0.00638^{* * *}$ & & \\
\hline & $(0.00193)$ & & & $(0.00202)$ & & \\
\hline \multirow{2}{*}{$\begin{array}{l}\text { Initial conditions } \\
\text { (VA/L) }\end{array}$} & $-0.125^{* * *}$ & $-0.124^{* * *}$ & $-0.0693^{* * *}$ & $-0.121^{* * *}$ & $-0.120^{* * *}$ & $-0.0650^{* * *}$ \\
\hline & $(0.00940)$ & $(0.00975)$ & $(0.00931)$ & $(0.00977)$ & $(0.0100)$ & $(0.00897)$ \\
\hline Observations & 781 & 781 & 781 & 781 & 781 & 781 \\
\hline R-squared & 0.752 & 0.748 & 0.650 & 0.739 & 0.735 & 0.649 \\
\hline Country fixed effects & yes & yes & yes & yes & yes & yes \\
\hline Industry fixed effects & yes & yes & yes & yes & yes & yes \\
\hline
\end{tabular}

Note: OLS estimates; the dependent variable is the annual growth rate of value added per full time equivalent at the country industry level for the period 1995-2005; OFF is service off-shoring intensity in 1995; îFF is the increase of service off-shoring over the period; ICT is the ratio of ICT capital to full time equivalent employees in the US; R\&D is the ratio of R\&D expenditure to full time equivalent employees in the US; K/L is the average capital per worker over the period; HK is an index of human capital; VA/L is the real value added per worker at the beginning of the period. All the variables are in log.

Robust standard errors in parentheses. ${ }^{\star \star \star} p<0.01,{ }^{* *} p<0.05,{ }^{*} p<0.1$

Columns 4 to 6 in Table 4 report the results for the same empirical model but substituting ICT with R\&D intensity. The positive and statistically significant estimate of the interaction coefficient indicates that productivity growth in R\&D intensive sectors was faster in countries with greater increases in service off-shoring over the period. The implied annual growth 
gap between an industry at the 75th percentile (Chemical) and an industry at the 25th percentile (Textile) of the R\&D intensity distribution is 1.1 percent higher in more compared to less service off-shoring oriented countries. These results confirm that the differential effect of R\&D is lower than that of ICT. It is relevant to note that this is just a within country and sector comparison that does not imply any conclusions on productivity growth differentials between countries or industries ${ }^{8}$ Our findings allow us to say that relatively to the country and industry averages, the productivity growth differential between high and low ICT/R\&D intensive sectors was higher in countries resorting more intensively to service off-shoring.

Table 5 - Differential effects - Service off-shoring Manufacturing industries

\begin{tabular}{lc|cc}
\hline & Initial effect & Initial effect & Improvement effect \\
ICT & 0.15 & 0.20 & 2.20 \\
R\&D & 0.05 & 0.10 & 1.10
\end{tabular}

Note: Initial level effect: the growth differential between more and less ICT intensive manufacturing industries is $0.1 \%$ higher in a country with service off-shoring at 25 th percentile than in a country at 75 th percentile in the initial year.

Improvement effect: the growth differential between more and less ICT intensive industries is $2.2 \%$ higher in a country with an increase of service off-shoring at 75th percentile than in a country at 25th percentile

\section{Conclusions}

This paper is an attempt to make some progress in our knowledge of the relation between service off-shoring and productivity growth. We tested whether higher initial service off-shoring intensity was associated with faster productivity growth in ICT intensive sectors in 1995-2005 in a sample of European economies. Then we analyzed the relation between increases in service off-shoring and productivity growth in technological intensive industries. We find that productivity growth was relatively faster in countries with higher service off-shoring at the beginning of the period. Our results show also that those countries where service off-shoring grew faster over the decade experienced faster productivity growth in ICT intensive sectors. We checked also for the differential effect of R\&D. We find a positive but smaller effect of R\&D compared to ICT. Consistently with the results by Abramovsky and Griffith (2009), showing that service off-shoring and ICT are strongly complementary, ICT plays a more relevant role than R\&D in explaining the mechanism through which service off-shoring affects productivity growth. Accordingly, the productivity enhancing effect of service off-shoring is relatively higher in more ICT intensive industries.

A lot of attention has been paid to the slowdown of productivity growth in the European economies compared to the US. The empirical literature shows that the main factor driving the divergence in productivity growth is

8 In our empirical model the growth differentials between countries are captured by the country and industry dummies. 
the relatively slower adoption of ICT in some European countries. As our results point out, also service off-shoring can be a key element in this respect. Our data document that those countries resorting more intensively to imports of intermediate services (Denmark, Sweden and Finland) are also the countries whose manufacturing sector is relatively more technologically developed and with the highest rates of productivity growth over the period. Thus if the strong complementarities between service off-shoring and ICT adoption are a fundamental element to stimulate productivity growth we should wonder if Europe is failing to exploit the growth potential of service off-shoring because of the relatively lower level of technological development as compared to the US. Future research will be devoted to analyze the role of other intangible assets in identifying alternative channels through which service off-shoring may affect productivity growth. 


\section{References}

Abramovsky L., Griffith, R. 2006. Outsourcing and offshoring of business services: How important is ICT?. Journal of the European Economic Association 4(2-3), 594-601. doi: 0.1162/jeea.2006.4.2-3.594

Abramovsky L., Griffith, R. 2009. ICT, corporate restructuring and productivity. IFS Working Papers W09/10, Institute for Fiscal Studies.

Acemoglu, D., Johnson, S., Mitton, T. 2009. Determinants of vertical integration: Financial development and contracting costs. Journal of Finance 64, 1251-1290. doi: 10.1111/j.1540-6261.2009.01464.x

Aghion, P., Hemous, D., Kharroubi, E. 2014. Cyclical fiscal policy, credit constraints, and industry growth. Journal of Monetary Economics 62, 4158. doi: 10.1016/j.jmoneco.2013.12.003

Aghion, P., Fally, T., Scarpetta, S. 2007. Credit constraints as a barrier to the entry and post-entry growth of Firms. Economic Policy 52, 731-779. doi: 10.1111/j.1468-0327.2007.00190.x

Amiti, M., Wei, S-J., 2006. Service offshoring and productivity: Evidence from the United States. The World Economy 32, 203-220. doi: 10.1111/j.1467-9701.2008.01149.x

Anderson, A., Gatignon, H. 1986. Modes of foreign entry: A transaction cost analysis and propositions. Journal of International Business Studies 17, 126. doi: 10.1057 / palgrave.jibs.8490432

Antràs, P., Helpman, E. 2004. Global sourcing. Journal of Political Economy $112,552-580$.

Braun, M., Larrain, B. 2005. Finance and the business cycle: International inter-industry evidence. Journal of Finance 60, 1097-1128. doi: 10.1111/j.1540-6261.2005.00757.x

Blinder, A. S. 2007. How many US jobs might be offshorable? CEPS Working Paper No. 142 (Brussels: Center for European Policy Studies).

Cetorelli, N., Strahan, P. 2006. Finance as a barrier to entry: Bank competition and industry structure in local US markets. Journal of Finance 61, 437-461. doi: 10.1111/j.1540-6261.2006.00841.x

Ciccone A., Papaioannou, E. 2007. Red tape and delayed entry. Journal of the European Economic Association 5, 444-458. doi: 10.1162/jeea.2007.5.23.444 
Ciccone A., Papaioannou, E. 2009. Human capital, the structure of production, and growth. The Review of Economics and Statistics 91, 66-82. doi: 10.1162/rest.91.1.66

Ciccone A., Papaioannou, E. 2009. Adjustment to target capital, finance, and growth. CEPR Discussion Paper 5969.

Cingano, F., Leonardi, M., Messina, J., Pica, G. 2010. The effect of employment protection legislation and financial market imperfections on investment: Evidence from a firm-level panel of EU countries. Economic Policy 25, 117-163. doi: 10.1111/j.1468-0327.2009.00235.x

Cuñat, A., Melitz., M. 2012. Volatility, labor market flexibility, and the pattern of comparative advantage. Journal of the European Economic Association, European Economic Association 10, 225-254. doi: 10.1111/j.15424774.2011.01038.x

Daveri F., Jona-Lasinio, C. 2008. Off-shoring and productivity growth in the Italian manufacturing industries. CESifo Economic Studies, vol. 3/08. doi: 10.1093/cesifo/ifn019

Edwards, S., 1998. Openness, productivity and growth: What do we really know? Economic Journal 108, 383-398. doi: 10.1111/1468-0297.00293

Feenstra R.C., Hanson, G.H. 1996. Globalization, off-shoring and wage Inequality. American Economic Review 86, 240-245.

Fisman, R., Love, I. 2007. Financial development and growth in the short and long run. Journal of the European Economic Association 5, 470-479.

Fratocchi L., Di Mauro C., Barbieri P., Nassimbeni G., Zanoni A. 2014. When manufacturing moves back: Concepts and questions. Journal of Purchasing and Supply Management 20, 54-59. doi: 10.1016/j.pursup.2014.01.004

Görg, H., Hanley, A. 2005. Labour demand effects of international outsourcing: Evidence from plant-level data. International Review of Economics \& Finance 14, 365-376. doi: 10.1016/j.iref.2004.12.007

Görg H., Hanley, A., Strobl, E. 2008. Productivity effects of international outsourcing: Evidence from plant-level data. Canadian Journal of Economics 41, 670-688. doi: 10.1111/j.1540-5982.2008.00481.x

Grossman, G.M., Helpman, E. 2002. Integration versus outsourcing in industry equilibrium. Quarterly Journal of Economics 117, 85-120. doi: 10.1162/003355302753399454

Grossman, G.M., Helpman, E. 2005. Outsourcing in a global economy. Review of Economic Studies 72, 135-159. 
Harrison A. 1996. Openness and growth: A time series, cross-country analysis for developing countries. Journal of Development Economics 48, 419447.

Klapper, L., Laeven, L., Rajan. R.G 2006. Entry Regulation as a Barrier to Entrepreneurship. Journal of Financial Economics 82, 591-629. doi: 10.1016/0304-3878(95)00042-9

Leamer E., Storper, M. 2001. The Economic Geography of the Internet Age. Journal of International Business Studies 32, 641-665.

Liu R., Feils D., Scholnick B. 2011. Why are different services outsourced to different countries?. Journal of International Business Studies 42, 558-571. doi: $10.1057 /$ palgrave.jibs.84909988

Liu, R., Trefler, D. 2008. Much ado about nothing: American jobs and the rise of service outsourcing to China and India. NBER Working Papers 14061, National Bureau of Economic Research, Inc.

Manova, K. 2008. Credit constraints, equity market liberalizations and International Trade. Journal of International Economics 76, 33-47. doi: 10.1016/j.jinteco.2008.03.008

Michelacci, C., Schivardi, F. 2008. Does idiosyncratic business risk matter for growth?. CEPR Discussion Paper 6910.

Nunn, N. 2007. Relationship-specificity, incomplete contracts, and the pattern of trade. Quarterly Journal of Economics 122, 569-600. doi: 10.1162/qjec.122.2.569

OECD 2007. Moving up the value chain: Staying competitive in the global economy. DSTI/IND 10.

Olsen K. B. 2006. Productivity impacts of offshoring and outsourcing: A review. OECD Science, Technology and Industry Working Papers 2006/1, OECD Publishing. doi: 0.1787/685237388034

Pagano, P. Schivardi, F. 2003. Firm size distribution and growth. Scandinavian Journal of Economics 105, 255-274. doi: 10.1111/1467-9442.t01-100008

Rajan, R. G., Zingales, L. 1998. Financial dependence and growth. American Economic Review 88, 559-586.

Rajan, R. G., Subramanian, A. 2011. Aid, Dutch disease, and manufacturing growth. Journal of Development Economics 94, 106-118. doi: 10.1016/j.jdeveco.2009.12.004 
Romalis, J. 2004. Factor proportions and the structure of commodity trade. American Economic Review 94, 67-97. doi: 0.1257/000282804322970715

Williamson, O.E. 1979. Transaction cost economics: The governance of contractual relations. Journal of Law and Economics 22, 233-261. doi: $10.1086 / 466942$ 